\title{
British Idealism and Political Theory
}

D. Boucher \& A. Vincent

Edinburgh University Press, Edinburgh, 2000, 256pp.

ISBN: 0-7486-1428-1.

Contemporary Political Theory (2002) 1, 256-258. DOI: 10.1057/palgrave.cpt.9300032

A book that deals with British Idealism and political theory, insofar as it aims to present the theories of the British Idealists faithfully while rendering them relevant and accessible to a contemporary readership, is taking on a complex and daunting task. British Idealism was a tradition of thought that incorporated a range of theorists and styles. Moreover, its academic preeminence in the latter part of the nineteenth century was followed by a rapid decline after the First World War so that an engagement with British Idealism must self-consciously retrieve its philosophical and political contexts from subsequent neglect. The historical retrieval of the characteristic preoccupations and standpoints of the British Idealists demands sensitivity to context and style. The British Idealists engaged with religious doctrines and sentiments, perceived the state in ethical terms and tended to adopt a tone of sobriety and earnestness. All of these features of their thought run counter to the more secular, circumspect style assumed by philosophers and political theorists in the Western world after World War Two. The British Idealists' elaborate metaphysics and grand theory by which an individual's identity is related to wider webs of meaning and political obligations are at odds with the fine-grained philosophical analysis practised by analytical philosophers and the empirical mindset of modern political science. The deconstructive turn of Continental theory is evidently a turn away from the elaboration of ideals of reason and ethics undertaken by the British Idealists.

It is to the credit of Boucher and Vincent that their book goes a long way in achieving the goal of making the British Idealists intelligible, interesting and relevant to contemporary philosophical and political projects without sacrificing authentic retrieval of historical context on the altar of passing fashion. The authors have eschewed presenting a generalized account of the British Idealists, opting instead to present intensive studies of individual Idealist thinkers'. A short introduction generalizes the perspective of the British Idealists, commenting on their Hegelian world view, their interests in religion and evolutionary notions, their ethical reading of state and society, and attesting to their influence beyond the UK. The heart of the book is its engagement with individual theorists. The rationale for this course of action is justified by the study itself in that the various theorists examined are shown to 
be distinct and to work in relation to specific contexts that are invoked in original, scholarly and thoughtful chapters on Green, Bosanquet, Bradley, Ritchie, Jones, Collingwood and Oakeshott. The selection of particular thinkers is inherently controversial when there are so many candidates from which to choose, but the selection of Oakeshott and Collingwood is to be welcomed as their work post-dating that of the heyday of British Idealism, shows the vitality of the tradition and its power in opposing fashionable postidealist orthodoxies.

The chapters on the particular theorists are original in discussing and assessing theories in fresh ways and in the light of interesting comparative contexts. Green is examined by observing the Hegelian aspects of his metaphysical writings and his post-Kantian standpoint is underlined by comparing his political theory to that of Rawls. Green's expansive and metaphysical sense of citizenship is counterpointed by observing Rawls's distrust of metaphysics and his preoccupation with setting limits to the conduct of politics. Insightful connections are made about the contextual specificity of both theorists, and the continued relevance of Green emerges out of the doubts cast on the limited reading of politics and citizenship offered by Rawls. Likewise, Collingwood's distinctive notion of civilization is presented and its contemporary relevance is underlined by relating it to current notions entertained by Rorty and Walzer. Oakeshott's considered review of the modern state in terms of ideal characters is reviewed in the light of its awkward relationship to his notions of philosophy and history and by relating his thought to contemporary theorists such as Dworkin and Gauthier. Bosanquet's thought is analysed via a focus upon his conception of the emerging discipline of sociology and more particularly through his reading of Durkheim, and his critique of positivist forms of sociology is shown to have a continuing relevance. Jones's engagement with liberalism and socialism is shown to bear upon our contemporary re-examination of the character of socialism. Ritchie's thought is approached by way of his idealistic assimilation of evolutionary theory and his critique of utilitarianism, while the polemic between Sidgwick and Bradley is retrieved in a study of Bradley that insinuates the relevance of his dialectical revision of modes of practice and thinking in the course of his Ethical Studies.

This book presents British Idealism as a complex internally differentiated tradition, an example of the concrete universal that figures in the metaphysics of British Idealism. The intricate and imaginative notions of civilization and citizenship that are invoked by the British Idealists are certainly conveyed as contrasting with more circumscribed styles of subsequent theorizing while possessing an affinity to current issues in theory and practice. The relevance of British Idealism for communitarianism and the New Labour project is canvassed, though the distinctive preoccupations and styles of British Idealism 
are also noted. Throughout the book, questions concerning the viability of the metaphysical standpoints of British Idealism and its characteristically ethical interpretation of state and society are posed without being answered definitively. Perhaps these questions do not admit of a general answer but are to be approached in terms of a critical reading of the particular arguments of individual theorists. If British Idealism is to be revived as well as retrieved, then this book will contribute to the sense that revisiting the theories of British Idealism can be productive in developing answers to current issues in contemporary political theory and practice.

Gary K. Browning Oxford Brookes University. 